\title{
The Bible Abbreviated: Summaries in Early Modern English Bibles
}

'Here I set no some: because I wolde all men shuld reade the chapter thorowoute' summary to Exodus 23, 1537 Matthew Bible

While organising preparation of the 1568 Bishops' Bible, Archbishop Matthew Parker gave the now-infamous instruction for the editors 'to make no bitter notis upon any text, or yet to set downe any determinacion in places of controversie." ${ }^{[1]}$ These 'bitter notis' chiefly recalled those of the Geneva Bible, which contained lengthier and more controversial paratexts than any previous English Bible. However, substantial paratexts were hardly unprecedented in early modern Bibles. ${ }^{[2]}$ From the medieval Glossa Ordinaria, whose pages held more paratext than scripture, to the authorised KJV, paratextual notes were an accepted and often extensive component of Bibles. Parker's rejection of 'bitter notis', though oft quoted, is not an attempt to banish paratextual content from Bibles but rather to ensure the paratexts were of the correct sort. The same desire arises with the KJV, whose editors were instructed to prefix 'new arguments [...] to every book, and new headings to every chapter', replacing those of the Bishops' Bible. ${ }^{[3]}$ Paratexts have only become the subject of sustained scholarship in recent years. Gérard Genette's landmark work on the topic, Seuils, did not see English translation until 1997, and although early modern paratexts have received increasing attention since then, $\frac{[4]}{}$ the paratexts of Bibles - arguably the most influential paratexts of any kind in the early modern period - remain neglected. ${ }^{[5]}$ These paratexts allowed noncanonical material into Bibles and conveyed politics and theologies that could influence interpretation and even prove seditious, as James I's aversion to the Genevan notes suggests. [6]

The limited existing scholarship on these paratexts focuses on glosses and marginal notes and almost entirely neglects other paratextual content, one of the most substantial types being the casus summarii, these being the chapter summaries that precede each chapter of nearly all early modern English Bibles. They list the following chapter's most notable features and aid in readers' navigation, which involves contracting thousands of words of scripture into a few dozen. Significant biblical events or controversial subjects can be condensed, omitted, reframed, rephrased, or otherwise represented to suit the editor's purposes. This article presents the first investigation into these summaries, focusing on those within the 1537 Matthew Bible, the Geneva Bible, and the KJV. ${ }^{[7]}$ These three Bibles were chosen because the Geneva and KJV, not being pulpit Bibles, had the widest effects on readers; the paratexts of the Matthew on the other hand became the basis of those in the Great, Bishops, and Geneva Bibles, and so though the Matthew has less direct influence on readers it is nonetheless one of the most significant early modern Bibles to paratextual study. For the sake of brevity, I will only discuss the major editions of these works and not re-editions with altered summaries. ${ }^{[8]}$ This article presents a table detailing the paratexts' transmission between Bibles, followed by three sections discussing their format, translation, and their effects on exegesis. It dwells on notable trends, anomalies, or other points of interest in each, aiming to demonstrate their importance and interest for future scholarship. In doing so, this article provides an introduction to one of the most neglected facets of the most influential books in the early modern period. 
Regarding terminology, the casus summarii comprise chapter summaries that appear before each chapter of the Bible, which normally excludes other forms of summary such as prefatory contents lists, running-heads, titles, and other synoptic media. Some Bibles, most notably the Geneva, contain in addition to the casus summarii another synopsis, the 'arguments', which appear before each book but not each chapter. Although 'arguments' is used broadly in early modern writings and can also denote the casus summarii, for the sake of clarity I will only use 'arguments' to refer to those synopses which bear the label.

These summaries are closely related in form, cultural role, and - occasionally - content to other types of biblical paraphrase. Paraphrases were a long-established facet of early modern encounters with scripture. Prior to the advent of vernacular translations, the lay English Christian's engagement with scripture would almost always be mediated by a third party, most obviously the priest as preacher, but also commentary, concordance, catechism, poetry, and, for the less learned, songs, stained glass, woodcut, textiles, and other visual interpretations. As James H. Morey writes, 'The Bible in the Middle Ages, much like the Bible today, consisted for the laity not of a set of texts within a canon but of those stories which, partly because of their liturgical significance and partly because of their picturesque and memorable qualities, formed a provisional "Bible" in the popular imagination. ${ }^{[9]}$ Before the popularisation of accessible print Bibles and the concordant increase in literacy, the Bible was not encountered as a book but rather a series of third-party paraphrases; "the Bible" was experienced as a patchwork of sermons, stories, poems, and pictures. Inheriting this tradition of scriptural engagement, the inclusion of chapter summaries in English Bibles would seem an entirely natural and explicable consequence, cemented by their long history in the Vulgate and, before that, the existence of marginalia and titloi in the earliest manuscripts.

Given this history, it is unsurprising that these summaries were reproduced as separate texts. A collection of the contents, of all the chapters contained in the Bible (1605), which was reprinted as S. H.'s A Diuine Dictionarie in 1615, was derived entirely from the casus summarii of the Great Bible and sought to serve mnemonic and organisational ends by reproducing noncanonical descriptors for the scriptures. From the preface 'To the Christian Reader': 'I could not so readily finde the same but by turning ouer a great Volume: now for the readier finding thereof, I haue made this briefe collection of the contents of all the Chapters conteined therein, whereby the same may be the more easily found' $[10]$ The work contains condensed forms of the chapter summaries, presenting a precis of a precis, as well as

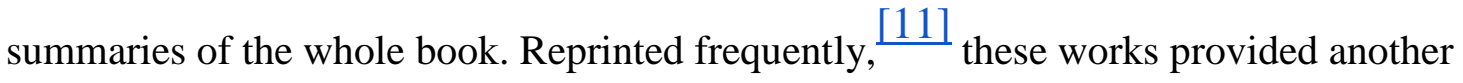
vehicle by which the casus summarii could be encountered, where they are divorced from scripture and treated as a useful authority in their own right.

The ubiquity and acceptance of the concept of the paraphrase results in there beinglittle explicit discussion of their role in early modern texts. The Geneva NT provides a rare exception:

they may serue in stede of a Commentarie to the Reader : for many reade the Scriptures with myndes to proffit, but because they do not consider the scope and purpose wherfore the holy Gost so writeth and to what ende (which tiling the Arguments do faithfully expresse) they either bestowe their tyme without fruit, or els defraude them selues of a great deale which they might atteyne vnto otherwise. To the intent therfore that, not onely they which are already aduanced in the knollage of the Scriptures, but also the simple and vnlearned might be forthered hereby, I haue so moderat them with playnenes and breuitie, that the verie ignorant may easely vnderstande them and beare them in memorie. And for this cause I haue 
applied but one argument to the foure Euangelists, chiefely for because that all writing of one matter, thogh by euery one diuersly handeled, they required no diuersitie of arguments. ${ }^{[12]}$

This preface prioritises the summaries' utility, presenting them as tools to aid efficient and accurate interpretation of scripture, as well as offering the mercurial advantage of 'seru[ing] in stede of a Commentarie to the Reader' and preventing the customer from needing to purchase additional commentaries. This is characteristic of the Geneva's use as a personal Bible and also, perhaps, of the lesser financial means of its intended demographic. They compete with other paraphrases; in aiming to displace commentaries, the summaries may offer instead a hegemonic, contained, authoritative explication of scripture. The presumed or even intended aim may be primarily humanistic - seeking to provide the unlearned with all the necessary tools to interpret scripture without necessitating clerical intervention or additional texts - but it also promotes interpretive homogeneity. The familiar paradox of Protestant humanism and anti-clerical attitudes is present: the Geneva Bible allows the unlearned physical access to scripture without need of a priest, but the necessary hermeneutic tools are also provided to ensure the reader constructs the 'correct' reading. Without these appropriate hermeneutic tools, the uneducated may 'defraude them selues of a great deale'. Similarly, under the guise of ensuring the accessibility of scripture to the unlearned, the Geneva proclaims its implicit modification of scripture in its synoptic goals: the scripture has been 'moderat[ed] [...] with playnenes and breuitie', implying the insufficient plainness of scripture (or of this translation).

The summaries themselves are highly intertextual and many were reused across the Bibles. The following table details the percentages by which English Bibles borrow casus summarii from their predecessors.

Given the lack of standardised spelling, textual analysis cannot be usefully employed to determine the similarity of two Bibles' summaries. This is compounded by the fact that many terms and phrases will appear describing the same passage (for example, references to character names) even if two summaries were produced independent of one another.

Therefore, this data was instead achieved by comparing each summary against those in the relevant Bibles and awarding it similarity level on a scale from 0 to 3 . Where two summaries were identical outside of minor grammatical discrepancies, $100 \%$ accuracy was assigned. Where two summaries contained entirely arbitrary and coincidental similarities, $0 \%$ was awarded. The final per-book percentage is derived from the mean average of this data, appropriately weighted according to the number of chapters per book. This means that if section $\mathrm{X}$ is marked $50 \%$ Bible $\mathrm{Y}$, this may designate 50\% summaries that are $100 \%$ matched, $100 \%$ that are $50 \%$ matched, or other combinations. These percentages are overlapping and not exclusive.

This table does not include the percentages taken from French Bibles, as meaningfully assessing the translation of French summaries cannot be achieved with a comparable degree of accuracy. It also excludes the Psalms and Song of Songs, which do not normally use casus summarii.

\section{Table of Intertextual Summaries}

\begin{tabular}{|l|l|l|l|l|l|}
\hline & $\begin{array}{l}\text { \% of } \\
\text { Matthew in } \\
\text { Great }\end{array}$ & $\begin{array}{l}\text { \% of Great } \\
\text { in Geneva }\end{array}$ & $\begin{array}{l}\text { \% of Geneva } \\
\text { in Bishops, }\end{array}$ & $\begin{array}{l}\text { \% of Great in } \\
\text { Bishops }\end{array}$ & $\begin{array}{l}\text { \% of } \\
\text { Bishops in } \\
\text { KJV }\end{array}$ \\
\hline Pentateuch & 69 & 17 & 31 & 28 & 0 \\
\hline
\end{tabular}




\begin{tabular}{|c|c|c|c|c|c|}
\hline $\begin{array}{l}\text { Historical } \\
\text { Books }\end{array}$ & 72 & 27 & 91 & 32 & 0 \\
\hline $\begin{array}{l}\text { Books of } \\
\text { Wisdom }\end{array}$ & 43 & 23 & 54 & 18 & 0 \\
\hline $\begin{array}{l}\text { Major } \\
\text { Prophets }\end{array}$ & 94 & 44 & 47 & 91 & 0 \\
\hline $\begin{array}{l}\text { Minor } \\
\text { Prophets }\end{array}$ & 98 & 50 & 83 & 58 & 0 \\
\hline Gospels & 95 & 29 & 21 & 33 & 16 \\
\hline Acts & 28 & 18 & 49 & 39 & 33 \\
\hline $\begin{array}{l}\text { Pauline } \\
\text { Epistles }\end{array}$ & 91 & 21 & 86 & 19 & 4 \\
\hline $\begin{array}{l}\text { General } \\
\text { Epistles }\end{array}$ & 79 & 46 & 94 & 43 & 7 \\
\hline $\begin{array}{l}\text { Apocalyptic } \\
\text { Writings }\end{array}$ & 22 & 40 & 100 & 35 & 6 \\
\hline
\end{tabular}

\section{Format}

In this section I will discuss the format and transmission of the casus summarii across the English Bibles. The casus summarii are highly intertextual and no Bible presents entirely new material for its summaries. If one wishes to investigate the origins of the $1611 \mathrm{KJV}$ paratexts one must look to the 1568 Bishops' that formed its base, from which one must look to the 1560 Geneva and 1539 Great Bibles from which that text borrowed; these Bibles in turn made use of the 1537 Matthew Bible, whereas both the Geneva and Matthew Bible made use of the 1534 Lefèvre and 1535 Olivétan French Bibles. From here we could work our way back into the medieval French and Vulgate Bibles from which these texts borrowed and some elements can ultimately be traced to the earliest Christian commentaries - but it is necessary to draw the line somewhere. Therefore, I begin in sixteenth century France, with the 1534 Lefèvre Bible, compiled by Jacques Lefèvre d'Étaples. It this Bible, with its copious paratexts, that provided Protestant martyr John Rogers with the source for the paratexts of the 1537 Matthew Bible.

The Lefèvre Bible provides the greatest early contribution to English biblical paratexts. The same cannot be said for Tyndale's NTs, despite providing the first casus summarii in an English Bible. ${ }^{[13]}$ The summaries of the 1535 Coverdale Bible, penned by Myles Coverdale, had more staying power, as Rogers combined the 1535 Coverdale summaries with those of the Lefèvre to form those of the Matthew Bible. Rogers redistributed Coverdale's summaries from a prefatory list appearing before each book to interstitial summaries appearing between each chapter, as was the common formatting in Vulgates. The chief effect of this shift is the frequency and mode with which the summaries are encountered. When summaries appear before each chapter, they must be read or consciously skipped. Furthermore, reading a summary immediately before the chapter promotes much stronger links between the 
summary and the scripture than summaries read in bulk at the beginning of a book. Rogers' placement ensures a greater integration of paratext.

While publication of what would eventually become the Bishops' Bible continued to delay, Thomas Cromwell and Thomas Cranmer commissioned Coverdale to revise the Matthew Bible to provide an English vernacular Bible in the interim. Coverdale used the Matthew Bible as his base, augmenting it with translations from the Vulgate and German Bibles. It is an entirely minor revision of the Matthew and David Daniell writes succinctly that there is 'little change' between the two editions. ${ }^{[14]}$ Though Daniell makes this comment about the translation, it is similarly applicable to the paratextual content. In over half of the books of the Great Bible, the summaries are over $90 \%$ identical to those of the Matthew; among the others, nearly all are still over $60 \%$ identical. Between the English Bibles, there are greater similarities between the Great and Matthew summaries than there are between those of any other two Bibles, although the Bishops' similarity to the Geneva is not a distant second.

The Matthew Bible may have had little new to offer in the way of scriptural translation, being merely a revision of Tyndale and Coverdale's work, but it provided a wealth of new paratextual material - or, at least, paratextual material that was new to English audiences. The Great Bible makes fewer inventions. It omits much of the contentious preliminary matter of the Matthew, including its rather Lutheran table of principal matters, but maintains many of the casus summarii. Its fidelity to the summaries of the OT and NT varies significantly, which is hardly surprising with Coverdale as reviser. Coverdale retains almost entirely the NT summaries of the Matthew Bible, which were themselves a repurposing of the prefatory summaries Coverdale authored for his 1535 Bible. Coverdale evidently judged these he had authored himself as needing little alteration, and many (including most of those of the gospels) are identical to those Coverdale first authored in 1535 as prefatory contents. Though amilestone in English vernacular Bibles, by the latter half of the sixteenth century the Great Bible had been outclassed by the Geneva; as Cleland Boyd McAfee writes, the Geneva 'drove the Great Bible off the field by sheer power of excellence." ${ }^{[15]}$ With its broad margins, running heads, numeration, and lucid, pleasing layout, the Geneva Bible established what became the familiar format of the English Bible. Its summaries are expansive, often twice or thrice the length of those in the Great and Matthew Bibles, and each book was preceded by an extensive Argument in addition to its summary. Much of the Arguments' content is Calvinistic; it is due to these Arguments that 'the English Geneva Bible delivered Calvin's theology to an English readership', as Femke Molekamp writes. ${ }^{[16]}$ The summaries are less theologically adventurous, though some important examples will be discussed in section three. One innovation entails the integration of verse numbers into the summary, so it is clear exactly to what part of the scripture the parts of these longer summaries correspond. This also has the effect of reconceptualising the summary as a series of shorter summaries attached discretely to scriptural passages, rather than a single grand summing up of the entire passage. Exceptions to this usually comprise summaries of laws, genealogical lists, and prophecies. This facilitates the conceptualisation of chapters broken into discrete chunks rather than a single concept, which is exacerbated by the further abstraction of these chunks as running-heads.

The Geneva's formatting was mimicked by the Bishops' Bible, including its long summaries, though the 'Arguments' are dropped. The Bishops' was the primary authorised pulpit Bible from 1568 to 1611, though it continued to be printed into the 1630s. Given Archbishop Parker's rule against 'bitter notis', one might expect the Bishops' Bible to depart drastically from the paratexts of its forebears, yet the Bishops' replicated not only much of the formatting but also the content of the Geneva summaries. This is especially true of the NT, in 
which nearly all summaries from 1 Cor onwards are copied from the Geneva. It is uncertain who was their author and compiler, though the evidence suggests Parker; in the 'Note as to the translators' Parker allocates to himself the authorship of various prefatory materials, including 'The argument of the scriptures', so he is most likely the compiler of the casus summarii. $[17]$

The KJV follows in the example of the Bishops' and Geneva when it comes to formatting and layout, though it had the most significant break in the content of casus summarii in all English Bibles. It is far more difficult to establish the extent to which the KJV borrowed from its predecessors than earlier Bibles, as augmentations to summaries in other Bibles are usually far less integrated. For example, Gen 3 of the Matthew Bible is summarised thus: 'The serpent deceaveth the woman. The serpe[n]t the woman \& the man are cursed / and dryven out of Paradise. Christ oure sauvour is promysed.' This is modified in the Great Bible as the following: 'The serpent deceyueth the woman. The serpent is cursed: the punishment of the man and woman. Adam driuen out of Paradise. Chryste our sauyour is promysed.' The alterations can be clearly delineated. In the KJV summaries, there are enough terms and phrases in common with the Bishops' Bible that it is clear some extent of influence occurs, but it cannot be easily reduced to a percentage. This is most true of the NT summaries, and the OT summaries may be completely new inventions. This would accord with the editors' instruction to create 'new headings' and 'new arguments' for the Bible, though even with this instruction the summaries produced were still not entirely new; repackaging of existing content as new material is hardly a novel phenomenon among biblical editors. The KJV summaries have unsurprisingly enjoyed the greatest longevity among the summaries of early modern Bibles and are still used today to aid navigation of the KJV text.

\section{Translation}

Although the primary aim of these Bibles was to provide English translations of scripture, they also often provided English translations of continental paratexts. The Bibles to which this is most directly relevant are the Matthew and Geneva Bibles, but translated paratexts appear throughout these Bibles as later editors copy the material of their predecessors. The first to feature substantially translated paratexts is the Matthew Bible. Its editor, John Rogers, has not received much critical attention outside of Joseph Lemuel Chester's nineteenth century biographical text,,$[18]$ and little new research had been conducted on his work. This is unfortunate, as Rogers' editorial practices had lasting effects on the shape and content of English Bibles; as David Daniell writes, Rogers' editing 'was pioneer work in Protestant glossing in English. ' $[19]$ Rogers assembled a wealth of paratextual content for the Matthew Bible, including 'The Summe [and] content of all the holy Scripture', 'A Table of the pryncipall matters conteyned in the Byble', running-heads, casus summarii, prologues, and an index titled 'the Table wherin ye shall fynde the Epistles and the Gospels'. Much of this was translated from the 1534 Lefèvre and its successor, the 1535 Olivétan, ${ }^{[20]}$ including the casus summarii of the Lefèvre OT; however, Rogers' translations are not as faithful as is usually assumed. $[21]$

There has been little scholarly discussion of Rogers' translatory practices. Molekamp simply writes, as is exemplary of critical attitudes to Rogers' paratexts, 'Many of the English paratexts 
are direct translations of those found in the French Bibles. ${ }^{[22]}$ This is indeed true of some of the paratexts, such as Thomas Malingre's 'Indice des principales matieres' which became Rogers' 'Table of pryncypall matters'. This alphabetical topic list with scriptural references is extremely faithful in content and layout, but Rogers was not so faithful when it came to the summaries. These are derived not from the 1535 Olivétan but the earlier 1534 Lefèvre Bible. ${ }^{[23]}$ Rogers' interpretation of these summaries varies in fidelity. Sometimes he presents verbatim English renderings of the French vocabulary and syntax, and sometimes he departs to so great an extent that the result should be taken as his own invention entirely.

Although these paratexts are usually referred to as translations, much oftheir content is pure Rogers, and other elements clearly draw on Coverdale's OT summaries. The Lefèvre casus summarii usually summarise scripture without adjectival flourish or editorialising interjection, whereas Rogers' Rogers' translations, when they diverge, are invariably longer and more evocative, some examples of which I will discuss below. For the NT, on the other hand, Rogers opted to use the summaries Coverdale had written as prefatory matter for the 1535 Coverdale Bible; these are lifted identically. $[24]$

Regarding Rogers' translations of the marginal notes, James Mozley writes, 'In dealing with his borrowed material Rogers uses various methods: the short notes are often taken over verbatim, but he sometimes alters the wording, enlarges what he has received, combines the opinions of two or three interpreters, adds a sentence of his own. ${ }^{[25]}$ In reducing Rogers' contributions to merely translations of the French, we overlook notable aspects of the work, some of which had lasting repercussions for later editions.

One such repercussion concerns Rogers' translation and interpretation of references to sin, wickedness, and transgression in the paratexts. In the Matthew Bible, Rogers translates many paratextual references to sin, yet he tends to collapse a wider variety of French vocabulary into more limited English terms. This happens frequently with 'wicked' or 'wickedness'. Rogers translates a variety of disparate French terms as wicked or wickedness, such as 'mauvais' (4 Kgs 21, 3 Kgs 15), 'iniquite' (Job 16), and 'perverse' (Ezek 22). He also adds the term to comparably neutral summaries, introducing an element of moral judgment not present in the French. 'La desolation de Hierusalem par les Romains' introduces 'wycked Jewes' in Dan 9; 'linfidele' in Job 18 is expanded to 'unfaythfull [and] wyckyd'. In the summary to Ezek 22, as well as translating 'perverse' as 'wicked', Rogers adds entirely new references to both 'wyckednesses' and the 'wickednes of the people'. Jeremiah 31, a lengthy and original contribution of Rogers', includes the summary that the 'All the wycked dye in their wyckedness', prompting an intratextual reading with Ezek 3:19. The word is very common in Rogers' summaries and is used in translations and expansions of, as well as departures from, the French summaries. It appears more often than any other word suggesting moral judgment. Another example of this is Rogers' translation of a variety of French terms with a single English word, such as giving both 'fornicatresse' and 'femme paillard' as 'harlot' (Lev 21, Judg 11). He does similarly with references to 'idolatry', a term employs in Exod 34, Judg 4, Judg 6, Judg 13, and $3 \mathrm{Kgs} \mathrm{3;} \mathrm{in} \mathrm{Lefèvre,} \mathrm{the} \mathrm{word} \mathrm{is} \mathrm{only} \mathrm{present} \mathrm{in} \mathrm{Exod}$ 34. Even in Exod 34, however, the syntax differs, with the French 'ydolatrerie des gentils' translated as 'and their ydolatrie also'. 26$]$

The varying designation of sinners between paratexts produces some interesting phenomena. One such instance concerns the summary to Prov 1 and its synopsis of Prov 1:10. In Lefèvre, the casus summarium strikingly refers to the 'incitations voluptueuses des pecheurs', summarising Solomon's instructions to not consent to the invitations of sinners. The French translation of Proverbs references the 'pecheurs' and their attempts to attract, 'attirer', but the 
paratextual interpretation of this as 'incitations voluptueuses' is quite the departure. In the Matthew Bible, Rogers' maintains Coverdale's translation of Prov 1:10 urging one to 'co[n]sente not unto synners, if they entyce the', but he translates the French casus summarium with relative fidelity: 'We may not herke[n] unto the voluptuous provocacion [and] inticynges of synners.' This is maintained verbatim into the Great Bible but the reference to sinners' 'voluptuous provocation' is then dropped from the Bishops' Bible. The summaries to Prov 1 in the Bishops' retain the syntax and sense of the Great Bible summary, but mitigate the prurient phrasing of Lefèvre and Rogers. Given that the Bishops' Bible lifts casus summarii verbatim from the Great Bible and that these instances are too similar in syntax and vocabulary to their predecessors to be wholly new inventions, it is reasonable to conclude that the editors were consciously copying and mitigating the more characterful summaries of the Great Bible.

Another passage on transgression subject to paratextual disagreements is Gen 19, the destruction of Sodom. Rogers' summary for Gen 19 is the second-longest synopsis in the fifty chapters of Genesis, second only to Gen 1 . Here, Rogers' summary is not only a significant departure from the French but uniquely prurient: he describes 'The fylthy lustes of the Sodomytes'. Despite his usual predilection for 'wicked' and its derivates and that at Gen 19:7 Lot asks that the Sodomites do not act 'wickedly', Rogers instead uncharacteristically opts for a more prurient phrasing. The 'fylthy' is entirely absent from the scripture, though Tyndale's translation of Genesis included in the Matthew Bible does feature the word 'lust' in Gen 19:7. Here, the Sodomites say of the angels, 'brynge the[m] out unto us that we may

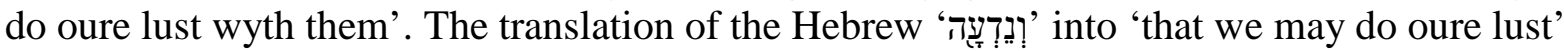
was not widely accepted by early modern translators; it was rejected by Coverdale and all subsequent revisers, who instead render this passage as 'that we may know them'. Although the 'lustes' of Rogers' paratext derive from Tyndale's translation of Gen 19:5, the 'fylthy' is entirely Rogers. Although later Bibles replaced Tyndale's translation of Gen 19:5, 'do oure lustes', with the more accurate 'know', Rogers' casus summarium remained. Both the Great Bible and the Geneva retained Rogers' 'the fylthy lustes of the Sodomites' despite eschewing the translation that led to their original inclusion. This is not the only instance in which Sodom will be treated with unusual paratextual emphasis, as will be discussed in the third section.

Another phenomenon concerns the translation of proper nouns. The denomination of

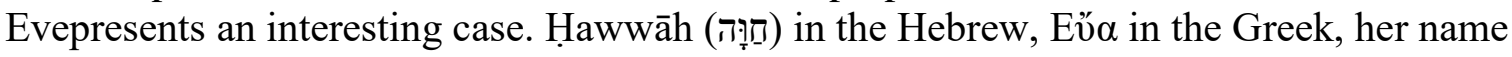
was variously translated as Eve, Eva, Heva, Hava, and Heváh in English Bibles. The name is translated inconsistently between scripture and summary, despite being rendered almost exclusively as either Eve or Eva in other texts. Why, when the OT scripture has been translated with a more Hebraic version of the name, do editors reject it in favour of the more common Eve or Eva in the summary? This question also concerns not only what she is called, but where, as most Bibles (Tyndale, Coverdale, Matthew, Great, Geneva, Bishops') give her name inconsistently between the OT and the NT. Come the KJV, Eve is only called by 'Eve', a decision prefigured by her paratextual designation which prioritises vernacular usage over accuracy.

The English convention of naming the first woman 'Eve' derives from the Vulgate. There, the name is rendered 'Eva' in both the Old and New Testaments. ${ }^{[27]}$ 'Eve' and 'Eva' had been the common English translations for the name of the first woman for centuries, but when translating from the Hebrew to English it became necessary to assess how that name should be translated, and if it should be translated in the same manner in both the Old and New Testaments. Tyndale accepted inconsistency and printed her name 'Eve' in the NT and 'Heva' in the OT. This NT designation is followed by every English Bible, but her OT 
denominations are not so consistent. Following Tyndale's lead, the Coverdale, Matthew, Great, and Bishops' Bibles name her 'Heva' in the scripture. In the summaries, however, she is 'Eva' in Coverdale and the Great Bible, she is 'Heva' in the Bishops', and she is unmentioned in the Matthew. ${ }^{[28]}$ Only the Taverner revision, the Douay-Rheims, and the KJV refer to Eve in all instances as Eve; all other Bibles contain some degree of variation. The Geneva Bible uniquely renders the name 'Heváh', and the Geneva does us the kindness of explaining the reasons for its naming practices. In the introduction to 'A brief table of the interpretation of the propre names which are chiefly founde in the olde Testame[n]t', wherein the meaning of 'Heváh' as 'liuing, or giuing life' is glossed, the naming practices of previous translators are condemned:

Whereas the wickednes of time, and the blindnes of the former age hathe bene suche that all things altogether haue bene abused and corrupted, so that the very right names of diuerse of the holie men named in the Scriptures haue bene forgotten, and now seme strange unto us, and the names of infants that shulde euer haue some godlie aduertisements in them, and shulde be memorials and markes of the children of God receiued into his housholde, hathe bene hereby also changed and made the signes and badges of idolatrie and heathenish impietie. $[29]$

These accusations of abuse and corruption are veiled attacks on those names popularised by Catholic use, a suggestion most lucid in the classically coded accusations of 'idolatrie and heathenish impietie'. For the Geneva translators, the restoration of 'Heváh' and removal of 'Eve' from the OT is a rejection of Catholic corruption. These attempts to introduce or restore an aspirated version of Eve's name were unsuccessful, as Heváh, Heva, and Hava are all rarely used in comparison to Eve or Eva and the spellings were not taken up by subsequent English Bibles.

While the Geneva translators might have tried to break from the corrupted tradition of 'Eve' in the OT, quite the reverse was true in the Coverdale, Taverner, and Great Bibles. Although this is doubtless in part due to the rendering of her name as 'Ev̈ $\alpha$ ' in the NT, the dominance of 'Eve' over the aspirated form is still unusual given the frequency with which the first books of Genesis were read and depicted. Colloquialism triumphed over accuracy. Relevant to this is the KJV's choice to translate the name as Eve in all instances; this stands against the translatory practices of the previous authorised Bibles which had used 'Heva' since the Tyndale translations. Speculation regarding the translators' motivations is not necessary in this instance, as Bishop Bancroft explains the methodology that led to this decision; he writes: 'The Names of the Prophets, and the Holy Writers, with the other Names of the Text, to be retained, as nigh as may be, accordingly as they were vulgarly used. '30] Here, 'Names' encompasses the proper nouns, including 'Eve', and this instruction for how such names were 'vulgarly used' includes the vernacular 'Eve'. Bancroft, then, instructs the translators to prefer the common, though more inaccurate, names over both those in the original languages and those chosen by earlier translators.

Eve is not the only figure to have her name altered in this way; Isaac is another whose corrupted, Anglicised, colloquial name triumphed over a more accurate moniker. Isaac's name, יצִחי in the Hebrew, was rendered 'Izhak' in the more Hebraic Geneva and 'Isahac' in the Bishops', but 'Isaac' remained the most popular form in England (and not coincidentally the form in which he is designated in casus summarii). As a result, he is 'Isaac' in the KJV. On the translation of Isaac's name, Jeffrey Shoulson writes, 'the King James translators are reassimilating a figure who threatened to become alien and exotic with an unfamiliar name 
[...] the King James translator's preferred name for the second patriarch effectively sustains

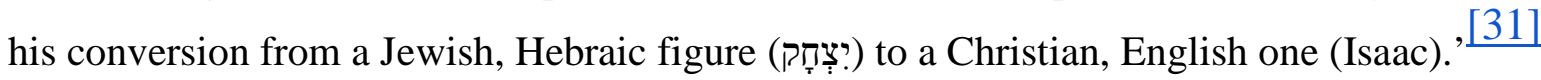
The same is true, even moreso, of Eve. Unlike Isaac, who is variably denoted 'Isaac' in the Coverdale and Great Bibles and 'Isahac' in the Bishops', Eve is consistently called 'Heva' in her OT references. Shoulson's emphasis here on the fear of these names becoming 'alien' and 'exotic' echoes the anxiety of the Geneva translators, whose acknowledgement of the Hebraic names becoming 'strange' is given as evidence for the restoration of those Hebraic names. By the KJV, that strangeness was no longer something to be rehabilitated but a reason for which such names should be rejected altogether. In rejecting the existing Hebraic legacy of naming the first woman 'Heva', the KJV not only established consistency in the English naming conventions between the Old and New Testaments, but definitively chose the popular, vernacular usage over accuracy. The legacy of Eve - and not Heva - is the triumph of the vernacular over Hebraic authority.

Whether this shift was facilitated by the summaries is difficult to determine, but it is certainly signposted by it. That the paratexts summarise scripture with less accurate, vernacular terms demonstrates an editorial willingness to sacrifice accuracy for familiarity and the acknowledgment that the vernacular is preferred for navigating the Bible, even if Hebraic terms are provided for the reading of scripture. A reader goes searching for Eve, not Heváh. In the Coverdale and Great Bibles, she may be 'Heva' in the scripture, but she is still 'Eve' in the summaries. This is 'corrected' to 'Heva' in the Bishops' summary, yet the correction is thrown out entirely in the KJV in favour of vernacular inaccuracy. While translators of scripture might try to present the most accurate translation of the names, the summaries reflect and participate in their practical use. The summaries thus act as barometers for when vernacular contradicts scripture.

\section{Exegesis}

David Crystal identifies 257 expressions that can be traced to the scripture of the KJV or its antecedent translations. ${ }^{[32]}$ The summaries, being at most $7 \%$ the length of the scripture, less widely read, and naturally less colourful, unsurprisingly do not yield influential expressions in anywhere near so great a number or as striking in tone. The only word I have found whose earliest instance may be traced to the KJV summaries is 'incorrigibleness'. The summaries are responsible, however, for popularising noncanonical titles of passages of scripture, some of which have had direct influences on hermeneutical practices. Among the most influential include the parable of the prodigal son, Esau selling his birth-right for pottage, and the sermon on the mount have had considerably more relevance to futurity. 'Parable of the $\mathrm{X}$ ' is a common construction for titles of passages, with titles such as the parable of the two eagles (Ezek 17) and the similitude of the wretched infant (Ezek 16) originating with or being popularised by the casus summarii. The most influential of these is the parable of the prodigal son (Luke 15:11-32), whose English usage is almost entirely a result of its inclusion in first the Matthew Bible 'Table of Principal Matters' and subsequent integration into the summaries of the Geneva, Bishops', and KJV Bibles. The passage had previously been known in English as the parable of the 'lost' son, but during the sixteenth century this was superseded by the parable of the 'prodigal' son. References to the son as a filius prodigus in Latin texts andfils prodigue in French were commonplace, but it was not until Rogers' translation of the 'prodigal' from Lefèvre's table that the word appeared in English Bibles and references to the 'prodigal son' became commonplace in English. This is not merely a linguistic trend. The term 'prodigal', meaning spending excessively, was best 
known from Aristotle's Nicomachean Ethics, and the prominent inclusion of 'prodigal' in these Bibles' summaries andrunning-heads resulted in a spate of Aristotelian exegeses of Luke 15.11-32, wherein Aristotle's theory of excess, moderation, and deficiency were applied to the prodigal son, liberal father, and miserly elder brother. ${ }^{[33]}$ To add to this, the Geneva and Bishops' Bibles both reference Christ's praise of 'liberality' in the summary to Luke 16, another word strongly associated with Aristotle's work, the inclusion of which is very likely inspired by the frequency with which Lukan economics were being read via Aristotle.

Another phrase codified by its inclusion in the summaries, though with less exegetical impact, is that of Esau selling his birth right for a mess of pottage (Gen 25:29-34). The phrase is wholly noncanonical, though it was already in vernacular use dating from the fifteenth century. ${ }^{[34]}$ The phrase 'Esau selleth his birth right for a messe of potage' is used in the Matthew and the Geneva summaries, integrating the colloquial 'mess of pottage' into the summaries. Despite the wide use of the phrase, the Great Bible, Bishops', and KJV drop it in favour of the more faithful 'Esau selleth his birth right', omitting the colloquialism. Unlike the denomination of Eve, this colloquialism was apparently too vulgar. A final example concerns the sermon on the mount, Matt 5-7. This title is less self-suggesting than it might appear, and did not in fact come into common use until the sixteenth century. Its English use and lasting popularity can be traed to Coverdale's casus summarium for Matt 5, which refers to 'the moste excellent [and] louinge Sermon of Christ in the mount'. The two aspects of this designation - the discourse being both a sermon and delivered on a mountain - are not derived directly from the text. Matthew 5 contains no reference to the discourse as a 'sermon', and even the translation of the location as 'mount' or 'mountain' was not universal. ${ }^{[35]}$ The title finds its earliest articulation in St Augustine, who titled his exegesis of the passages, 'De Sermone Domini in Monte secundum Matthaeum'. ${ }^{[36]}$ This Latin title was sufficiently widely used to appear as a title in the Vulgate, wherein the section is titled 'Sermo in monte'. Despite its Latin popularity, it is not until Coverdale that a comparable designation appears in English, wherein Matt 5 is first said to contain 'The Sermon unto Christ in the mount'. The English designation is sometimes dated to a later point, $\stackrel{[371}{ }$ but Coverdale appears to be the earliest instance, as Henry McArthur identifies. ${ }^{[38]}$ Coverdale certainly worked from the Vulgate, and the title has not been found in any English texts, so it seems Coverdale is its English originator.

These examples are easily traced by virtue of their linguistic particularity. Demonstrating hermeneutic trends not rooted in uncommon words or phrases is a more substantial task. I aim here to illustrate two examples of the summaries affecting exegetical trends by analysing the works of those writers who used the Bibles in which these summaries are contained. The first example concerns the seduction of Eve in Gen 3, the second the inclusion of 'sodomy' in Lev 20.

The concept of Eve's seduction concerns her culpability for the Fall as well as the extent to which there is a sexual element to both her deception by the serpent her giving of the forbidden fruit to Adam. 'To seduce' acquired its sexual suggestion in the late sixteenth century and many early modern uses of the term are nonsexual in nature, yet its increasingly sexual usage frequently occurs in reference to Eve. Though sexualised conceptions of the Fall have a long history, as in Petrarch's De viris illustribus, the specifically sexual usage of the English 'seduce' to describe the events of Gen 3 only developed during the late sixteenth and seventeenth centuries. I posit this usage is due in part to the Gen 3 summary in the Geneva Bible, wherein the events of Gen 3:1-5 are summarised as 'The woman seduced by the 
serpent', despite the absence of 'seduce' or its derivates in scripture. This section will examine the practical implications of the summaries' content by investigating the usage of 'seduce' throughout the work of writers who used the Geneva Bible, and argues that the paratextual inclusion of the term facilitated the sexualisation of Eve's deception and giving of the fruit.

Before discussing the Genevan paratext, we must address the contemporary context in which Gen 3:1-5 was interpreted. The most important text is the Vulgate, which contains two references to the events of Gen 3 that use seducere. These are 'Timeo autem ne sicut serpens Hevam seduxit astutia sua' (2 Cor 11:3) and 'et Adam non est seductus: mulier autem seducta in prævaricatione fuit' (1 Tim 2:14). The seductus/seducta of the Vulgate translation of Timothy will echo throughout early modern exegeses of Gen 3; however, whereas in Timothy this figures as a denial of Adam's seduction and citation of Eve's, the early modern repetition reconfigures this as Eve's seduction by the serpent and then Adam's seduction by Eve, as will be shown. The patristic conception of the seduction of Eve and the seduction of Adam as separate events are conflated into one phenomenon in such texts. As the Vulgate translation uses various forms of seducere, it is unsurprising the obvious English derivates (seduce, seduction) would also be used to refer to Gen 3; however, 'seduce' did not enter the English language until the fifteenth century, and it only retained its asexual Latinate meaning for about a century before developing a sexual connotation. Importantly, 2 Cor 11:3 and 1 Tim 2:14 are not translated with any form of 'seduce' in the Geneva translation. Excepting the Doauy-Rheims, all English translations used 'beguiled' for 2 Cor 11:3 uses and 'deceived' for 1 Tim 2:14. The Doauy-Rheims unsurprisingly translates the Vulgate's seduxit, seductas, and seducta as 'seduced' in all instances, and so Catholic exegeses of the Fall as a sexualised seduction are commonplace. Genesis 3.13, on the other hand, wherein Eve explains 'The serpent beguiled me' (Geneva) the verb is either 'beguiled' or 'deceived' in all English translations, including the Douay-Rheims; in the Vulgate, it is 'decepit'.

Despite the absence of any description of Gen 3 as a seduction in the Geneva Bible, exegetical descriptions of it as such by Geneva readers are commonplace. Its Gen 3 summary, 'The woman seduced by the serpent', likely hails from the French Bibles, as paratextual references to 'Le serpent seduict la femme' appear as a marginal note in the Olivétan and a summary in the Lefèvre. These French paratexts probably derive from 2 Cor 11:3 and 1 Tim $2: 14$, which both use 'seduict'. But the Geneva eschews the term in scripture, maintaining it only in the summary. There is, therefore, a disagreement between the Genevan scripture and its paratexts: to what extent is Eve beguiled and deceived, and to what extent is she seduced? It must be emphasised that the sexual meaning of seduce was not as prominent in the sixteenth century as it is today. It is not recorded in an early modern lexicon as having a sexual meaning until 1598, where in Florio's A World of Words the term is listed as a possible translation of 'vitiare', alongside 'rauish', 'deflowre' and 'sinne'. ${ }^{[39]}$ Interestingly, the earliest recorded use of 'seduce' in a sexual sense is 1560, the Geneva Bible's year of publication. ${ }^{[40]}$ Though the date is coincidental, it demonstrates this Bible entered the scene contemporaneously with the increased sexual understanding of the term. After 1560, descriptions of Gen 3 as a seduction and implications that this seduction is sexual in nature become increasingly common among Protestants who take the Geneva Bible as their text. The first point of evidence in favour of this trend is the scarcity of descriptions of Gen 3 as a seduction prior to the publication of the Geneva, despite its use in the Vulgate. Aside from two direct translations of the Vulgate, the only instance I have found is in in Thomas Cranmer's Certayne sermons (1547), with a reference to Eve having been 'seduced by the subtile perswasion of the Serpent'. ${ }^{[41]}$ This usage is rare compared to the rate at which 
instances appear after the publication of the Geneva. The writers discussed here all used the Geneva as their primary source for scripture, as can be ascertained by comparing their scriptural quotations with the translations of English Bibles.

In George Gifford's A catechisme conteining the summe of Christian religion (1583), the early presaging of what will later become an unambiguously sexual usage of 'seduce' is apparent. He writes, 'The Diuell in the Serpent did seduce the woman, perswading her that their estate shoulde bee bettered by eating of the fruite forbidden: she entised the man and so they sinned'. ${ }^{[42]}$ There is an echo of the parallelistic syntax of 1 Tim 2:14 here, 'Adam non est seductus: mulier autem seducta', with Gifford's 'the Serpent did seduce the woman [...] she entised the man'. The shift from 'seduce' to 'entise' moves from the more neutral 'seduce' to a term with a more prominent gendered and sensual, if not sexual, meaning. [43] This exaggeration of the scripture to emphasise the gendered, sensual, and sexual qualities of Eve's being-seduced and seduction-of were longstanding features of Genesis exegesis, but their grounding in the English 'seduce' will become more apparent in these texts.

Two texts in 1601 and 1610 by Nicholas Gibbons and Richard Stock respectively make more neutral use of the term, showing that it still had the capacity to suggest wholly nonsexual usage by the seventeenth century. ${ }^{[44]}$ The 1607 Certain godly and learned sermons by Edward Philips' is more carnal, however, and departs rather bizarrely from scripture. For Philips, it is necessary to invent several motivations and actions on Eve's behalf. He writes, 'the Serpent indeed blew the coles, but the fire was in her owne heart, and she would not confesse that shee abused her selfe to bee seduced by the Serpent'. ${ }^{[45]}$ This 'fire' in Eve's 'heart' is entirely Philips' invention and reconfigures the serpent's seduction from a corruption of innocence to the encouragement of an existing sinful impulse, totally contrary to the idea of prelapsarian innocence. In Philips, for Eve at least, there was no state of innocence. He then asserts fictitiously that Eve 'would not confesse' of her seduction, despite Eve quite clearly doing so at Gen 3:13: 'Why hast thou done this? And the woman said, The serpent beguiled me, and I did eate.' It is implied in Philips that Adam having confessed first (Gen 3:12) to eating the fruit nullifies Eve's own confession. The imagery of fire, coals, and Eve having 'abused' herself enhances the damnatory and carnal invention of Eve's prelapsarian sin, and finally, this invention makes it entirely and emphatically Eve, rather than the serpent, who is at fault for the Fall. Philips' syntax, 'seduced by the serpent', is exactly that of the summary.

This form of sexualised misogyny is particularly apparent in Joseph Hall's 1612 work, Contemplations vpon the principall passages of the holy storie, and it is here the idea of the 'seduction' of Eve is presented as itself directly sexual as opposed to being merely associated with sexuality, as in Philips. Hall writes, 'A woman seduced Adam, women betray these sons of God, the beauty of the apple betrayd the woman, the beauty of these women betrayd this holy seed, Eue saw and lusted, so did they, this also was a forbidden fruit, they lusted, tasted, sinned, died'. ${ }^{[46]}$ The three points of sexual suggestion here comprise the emphasis on Eve's beauty, the betrayal of seed, and the repetition of 'lust'. Eve's deception by the serpent is here reconfigured as a knowing betrayal of Adam, absolving the first man entirely for the Fall. Despite Eve's canonical giving of the fruit to Adam being based entirely on her assessment of the goodness of the fruit (Gen 3:6), Hall roots the responsibility in Eve's 'beauty'; for Hall, the fruit being 'pleasant to the eyes' becomes 'the beauty of the fruit', which is then elided with the 'beauty' of Eve, and herein lies the blame for the Fall. The semenic suggestion of the genealogical 'seed' heightens this, though it is the repetition of 'lust' that elevates this reading to sexual extremes. In Hall's rewriting of the Fall, Eve harbours a sexualised desire 
for a fruit that mirrors her own beauty, and with her beauty she knowingly betrays Adam's patrilineage through their shared lust. Hall's misogyny is likely prompted by the Pauline reference to Eve having 'deceived Adam' (1 Tim 2:14), but his interpretation of Genesis roots that sexual reading to the noncanonical 'seduce'.

Another misogynistic reading, contemporary to Hall, is Thomas Bentley's The sixt lampe of virginitie (1612). Bentley quotes scripture with a parenthetical insertion of his own exegesis: 'THE Lord God said vnto the first woman Eue [which being seduced by the serpent, did first taste, and afterward entised her husband Adam to eate of the forbidden fruite in Paradise, contrarie to Gods commaundement] Woman, why hast thou done this? ${ }^{[471}$ The work is an often misogynistic instructional text directed at women, telling of 'the seuerall duties and office of all sorts of women in their vocation out of Gods word, with their due praise and dispraise by the same'. The section in which this quote appears is titled 'The penal punishmentes, and terrible threatnings of God in his worde, against all sortes of vngodlie women, for their sinnes and wickednesses' and perhaps unsurprisingly makes no mention of any fault of Adam in Gen 3. No typographical shift marks the end of his quotation of scripture and he shifts immediately into misogynistic exegesis, writing that 'Thus doth the Lorde punish the bodie of woman'. Again, Eve's giving of the fruit to Adam becomes an 'entise[ment]'. The sexual suggestion, though less emphatic than Hall's hypersexualised reinterpretation, is nonetheless present. 1 Timothy 2:14 might be seen informing Bentley's parenthetical exegesis, wherein the parallel deceive/deceived becomes Eve 'being seduced by the serpent [...] and afterward entised her husband'; however, the Pauline reading of Eve simply repeating the actions of the serpent in deceived/deceived, which might cast her as more blameless, is eroded into the exaggeration of seduce/entice.

A third contemporary text is Francis Rollenson's Twelue prophetical legacies (1612). Rollenson's topic is the pains of conception and childbirth, related in uncomfortably graphic detail with reference to women being 'ript vp' before delivery. He lists the various discomforts and pains to which the pregnant and delivering female body is subject, citing Pliny, Aristotle, and St Basil, all of which are a result of Eve having been 'seduced by the Serpent'. ${ }^{[48]}$ There is no reference to Paul here, and Rollenson's phrase immediately precedes the quoted scripture from Gen 3:16, mimicking the formatting of the Geneva's prefatory summary. His description of Eve having been 'seduced by the Serpent' is identical to the paratextual syntax.

Finally, Robert Wolcomb's A glasse for the godly (1612) offers an exegesis with the characteristic absolution of Adam's blame in favour of Eve as the corrupted corrupter. Wolcomb exhibits a peculiar bias in which he and his readers are allied with Adam against Eve. He writes, 'should we not haue cried out and said vnto him; ô thou wretch, take heede to thy selfe; see thou doe it not; the woman is seduced; beleeue not her entisements?' Again, Eve offering Adam the fruit becomes the far more suggestive 'entisement'. There is also the familiar introduction ofa verbal component to Eve's offering to Adam of the fruit, which in scripture is an entirely physical act. This idea, what Petrarch calls the 'sussurro femmineo', of Eve's having addressed Adam with a linguistic enticement transfigures the giving of fruit into a verbal seduction. ${ }^{[49]}$ As for the grammar, Wolcomb's 'seduced' here shifts from a transitive verb to an adjectival state; seduction is not an action the serpent performs on Eve, but a transformative process that renders her 'seduced' and therefore corrupt. It is because of this corruption, Wolcomb implies, that Adam should not have believed her, Finally, Wolcomb continues his interpretation of the giving of the fruit as a discursive situation by arguing that he and the (presumed male) reader would have tried to prevent the Fall by rhetorical means: 'Should this haue béene our perswasion to Adam, that he should looke to himselfe, and shal we not perswade our selues after the same manner, when we are compassed \& thronged with the like tentations? ${ }^{501}$ If we could speak to Adam this precis 
of Deut 4:9 then the Fall could have perhaps been prevented. Wolcomb's reading is less exegesis than reinterpretation, one in which Eve's seduction is reified into a corrupting process. Here, then, the seduction of Eve is no longer the transitive deception by the serpent but a state of corrupt and sexual seduction.

During the fifty years from the publication of the Geneva Bible and the earliest recorded sexual use of 'seduce', to the publication of the KJV and Hall, Rollenson, and Wolcomb's exegeses, 'seduce' has acquired a prominent sexual meaning. In these texts we see Gen 3 continually conceptualised as a seduction by exegetes who use the Geneva as their source, despite the absence of any such reference to the event as a seduction in scripture. The only reference to Gen 3 as a seduction is paratextual. In the absence of scriptural corroboration, the term remains and enables sexual and misogynistic readings of the Fall. In the absence of any other direct source, the Genevan paratext must be considered a contributing factor.

My second example concerns the summary to Lev 20 in the KJV, which contains the following: ' 10 Of adulterie. 11. 14. 17. 19 Of Incest. 13 Of Sodomie. 15 Of Beastialitie. 18 Of uncleannesse.' This '13 Of Sodomie' references Lev 20:13, 'If a man also lie with mankind, as he lieth with a woman, both of them have committed an abomination', though it also has close association with Lev 18:22, 'Thou shalt not lie with mankind, as with womankind: it [is] abomination'. In this summary, Lev 20:13 is plainly referred to as a description 'Of Sodomie.' The term introduces an interesting recursive intratextuality, as the passage itself makes no reference to Sodom or Gen 19. Such intratextuality is unusual in casus summarii, as such practices are left to the purpose of cross-referential marginal notes, and among the many such notes to Lev 20 there is no encouragement to turn to Gen 19. This use of 'Sodomie', then, is less an encouragement to crossreferential reading or a deliberate moment of intratextuality but rather the editor's deferment to the contemporarycommon usage of sodomy to denote homosexual acts which derives from Gen 19. Sodomy was not the favoured legal term; this was 'buggery', according to the Buggery Act 1533, and it could refer to penetrative bestiality or homosexual anal intercourse. Sodomy retained a similar semantic broadness, also being used to denote bestiality, and there is a discrepancy between the early modern English usage of the term and its paratextual role here wherein it strictly denotes a man ' $1[$ ying] with mankind'. Bestiality is given its own category, '15 Of Beastialitie', denoting Lev 20:15. There is then a blurring here between the twin meanings of sodomy denoting specific sexual acts and the ambiguousness of the Levitican 'lie with', though my interest here is rather in the codification of sodomy by religious writers as the descriptor for the acts described in Leviticus 20:13 and 18:22. I suggest that the inclusion of 'sodomy' in the KJV summary functions taxonomically in contrast to the other sexual acts listed (adultery, incest, bestiality, uncleanness), that the word as descriptor for the acts described in Lev 20:13 and 18:22 were taken up by subsequent writers as a result of this inclusion, and that this contributed to the codification of 'sodomy' as the name of such acts as described in Leviticus.

Despite the lexis of sodomy having been associated with homosexual acts since at least Augustine's exegesis of Gen 19, I can find no English instance of the Levitican passages described as such until $1591^{[51]}$ and only one Vulgate quotation to do so. $\frac{[52]}{\text { There are }}$ likely earlier extant examples, but the difficulty of finding them nonetheless indicates comparative scarcity to their frequency post-1611. Notably, though the association between 'sodomy' and intermale sex was longstanding, it is not until 1656 that an early modern lexicon establishes the connection, ${ }^{[53]}$ though there are casual uses of the definition predating this. After the publication of the KJV, wherein Lev 20:13 is explicitly described as sodomy by the summary, instances of primarily religious writers describing Lev 20:13 as such begin to occur far more frequently. Other than Perkins' 1591 text, all other English quotations of Leviticus labelled sodomy I have found postdate the publication of the KJV. The summary was, therefore, likely a contributor to this usage.

One common trend is for writers to simply cite Leviticus as the definition of sodomy. Henry Ainsworth (1627) provides an early example. He writes of the "unnaturall sin, which the 
Scripture calleth lying with the male, Lev. 18. 22. and 20. 13. is calledSodomy, as being first practised in Sodom, and the cities about it'. ${ }^{[54]}$ When Ainsworth writes that this sin 'is called Sodomy', he omits the authority making such a definition and the citation of what 'Scripture calleth' the 'unnaturall sin' immediately prior confuses the source from which the denotation of sodomy derives. A similar phenomenon occurs in Samuel Danforth's The Cry of Sodom (1674), wherein Danforth cites Lev 20:13 and referencing the titling of this act as 'called Sodomy'. He exaggerates Gen 19 and subsequently confuses the etymology of the term: 'This sin raged amongst the Sodomites, and to their perpetual Infamy, it is called Sodomy.' It is unclear among whom this 'infamy' has developed, and Danforth's phrasing suggests that the definition may derive from scripture despite this being inaccurate. John Trapp (1649) again quotes Lev. 18:22 and calls it 'The Sodomites sin', as does a 1647 anonymous text. [55] Lancelot Andrewes' The pattern of catechistical doctrine at large (1650) has a more interesting usage, as he formats sodomy as a navigational marginal note. ${ }^{[56]}$ Andrewes' marginal notes are otherwise almost entirely scriptural citations, mimicking the use of crossreferential notes in the Bibles themselves, and most that are not scriptural references act as navigational titles (the section on 'uncleanesse' also uses rape, whoring, and polygamy). Sodomy, then, is not here merely a descriptor invoked for its recollection of Gen 19 but a navigational descriptor, performing an analogous navigational function as it does in the KJV. ${ }^{[57]}$ This kind of taxonomic use appears again in George Mackenzie's The laws and customes of Scotland (1678). Despite the legal conflation of bestiality and homosexual acts under the single category of 'buggery', Mackenzie maintains a distinction between the behaviours. He quotes Lev 20:13-15 as detailing sodomy and bestiality, two terms both absent in the scripture yet present in the summary. ${ }^{[58]}$ This replication of the summary as a kind of taxonomy of the behaviours discussed in Lev 20 is repeated more extensively in Samuel Cradock (1683) where it is very clearly derived directly from the KJV summary. Here, Cradock reproduces the taxonomy of the KJV summary as a bullet pointed contents list for describing those behaviours which 'we are forbidden'. As can be seen with reference to the KJV summary, Cradock's taxonomy is a straight derivation. His list comprises: Fornication with a Bond-Maid betrothed, Adultery, Incest, Sodomy, Bestiality, and Lying with a woman having her Sickness. ${ }^{[59]}$ Cradock makes frequent reference to Lev 20 in this section, and aside from the expulsion of adultery into two categories and the rephrasing of menstruation from uncleanness to 'a woman having her sickness', the taxonomies are identical in order and vocabulary.

The minister John Webster in his The displaying of supposed witchcraft (1677) advances this taxonomical habit to the point of implying Moses makes direct use of the term 'sodomy'. When arguing for the fictitiousness of claims for the existence of copulation with Devils, Webster reasons that, since Moses makes no reference to the act amongst those prohibited sexual acts in Leviticus, it is unlikely to be a true occurrence. In referencing the topics Moses discusses, Webster erroneously claims, 'Moses [...] named and prohibited the less sins of bestial Copulation and Sodomy'. While Moses' description of how man must not 'lie with a beast' (Lev 20:13) is semantically close to 'bestial copulation', there is no instance in which Moses describes man '1[ying] with mankind, as he lieth with a woman' as 'sodomy'. This should not be taken as a misquoting of scripture; Webster is not claiming Moses literally described the act as 'sodomy'. What occurs here is the complete absorption of the Levitican description into the word sodomy to such a great extent that Webster can use the term interchangeably with the scriptural quotation itself. Sodomy is no longer here an act merely 
associated with homosexual acts or one possible interpretation of Gen 19, but an interchangeable synonym for when 'man lie with mankind'. [60] By the latter half of the seventeenth century, the term also appears in a similar manner in legal texts, with the Levitican description given as the definition for sodomy. ${ }^{[61]}$ The frequent citation of sodomy in conjunction with Lev 20:13, that such citation is unusual prior to the publication of the KJV, and that such citations often replicate the taxonomic role or format of the summary strongly suggest the inclusion of 'sodomy' in the Lev 20 summary contributed to both its association with the passage and its general use to denote homosexual acts.

\section{Conclusion}

Even if we are tempted to see claims summarising the KJV - such as David Norton's declaration that it is 'The most important book in English religion and culture' and Gordon Campbell's that it is 'the most celebrated book in the English-speaking world' - as a tad hyperbolic, there is no shying away from the KJV's status as a book of paramount influence. ${ }^{[62]}$ It should, then, go without saying that its paratexts are also worthy of committed scholarship, and those works that shaped those paratexts' form and content should be similarly deserving of critical consideration. Even setting aside such acclaim for the KJV, these texts were each vital and important works in their day and their study is of significant benefit to early modern scholarship. The casus summarii, however, are only one form of synoptic biblical paratext. Along with the arguments, contents lists, indices, topic tables, titles, and running heads, the amount of synoptic content in early modern Bibles comprises an intimidating corpus, and one worthy of further attention. There is much contained in early modern Bibles beyond the scripture, and this article has aimed to demonstrate the importance of attending to it.

[1] MatthewParker, "Parker's note as to the translators," Records of the English Bible (ed. A. W. Pollard; London: Oxford University Press, 1911) at 297.

[2] I align my definition of 'paratext' with that of the ParaTexBib project on early Greek biblical paratexts: 'all contents in biblical manuscripts except the biblical text itself are $a$ priori paratexts.' Martin Wallraff and Patrick Andrist, "Paratexts of the Bible: A New Research Project on Greek Textual Transmission," Early Christianity, 6.2 (2015) 237-43, at 239.

[3]

"Report to the Synod of Dort," Records of the English Bible (ed. Pollard) at 339.

${ }^{[4]}$ See Renaissance Paratexts (ed. H. Smith and L. Wilson; Cambridge: Cambridge University Press, 2011); William E. Slights, Managing Readers (Ann Arbor: University of Michigan Press, 2001); Evelyn Tribble, Margins and Marginality (London: University of Press of Virginia, 1993).

[5]

For work on biblical paratexts, see James Frederic Mozley, Coverdale and His Bibles (London: Lutterworth Press, 1953) at 84-6, 142-66; Brooke Foss Westcott, A General View of the History of the English Bible, 3rd (ed., Rev. William Aldis Wright; London: MacMillan and Co., 1905); David Daniell, The Bible in English (London: Yale University Press, 2003); 
Femke Molekamp, "The Geneva and the King James Bibles: Legacies of reading practices," Bunyan Studies xv (2011) 11-25 and "Genevan legacies," The Oxford Handbook of the Bible in Early Modern England, c. 1530 - 1700 (ed. Kevin Killeen, Helen Smith, and Rachel Judith Willie; Oxford: Oxford University Press, 2015) at 46-8; Maurice S. Betteridge, "The bitter notes: The Geneva Bible and its annotations," The Sixteenth Century Journal, xiv.i (1983) 41-62; Vivienne Westbrook, Long Travail and Great Paynes: A Politics of Reformation Revision (Boston: Kluwer Academic, 2001) at 143-80; S. L. Greenslade, "English Versions of the Bible,"The Cambridge History of the Bible: The West from the Reformation to the Present Day (ed. S. L. Greenslade; vol. 3 of The Cambridge History of the Bible; Cambridge: Cambridge University Press, 1975) at 141-74; Jack P. Lewis, The Day after Domesday: The Making of the Bishops' Bible (Wipf \& Stock Publishers: 2016).

[6] “ "Introduction," Records of the English Bible (ed. Pollard) at 46.

$[7]$

Unless otherwise indicated, the editions cited are The Matthew Bible, The Byble: which is all the holy Scripture: in whych are contayned the Olde and Newe Testament (Antwerp[?]: 1537); the Geneva Bible, The Bible and Holy Scriptures conteyned in the Olde and Newe Testament (Geneva: 1560); the KJV, The Holy Bible (London: 1613). Other editions include the 1535 Coverdale Bible, Biblia: The Byble: that is the holy Scrypture of the Olde and New Testament ([Cologne or Marburg]: 1535); The Great Bible, The Byble in Englyshe, that is to saye the conte[n]t of al the holy scrypture (London: 1539); and the Bishops' Bible, The holie Bible (London: 1568).

[8],

These other editions with altered summaries most notably include Richard Taverner's Bible, Edmund Becke's Bibles, and the 1572 revision of the Bishops' Bible.

[9] James H. Morey, "Peter Comestor, Biblical Paraphrase, and the Medieval Popular Bible," Speculum, 68.1 (1993) at 6.

${ }^{[10]}$ H. S., A diuine dictionarie, or, The Bible abreuiated Containing the whole Scripture (London: 1615) n. pag.

111 A diuine dictionarie, itself a reprint of Hill's work, was reprinted in 1615, 1616, and 1617.

$112]$ "Preface to Geneva New Testament," Records of the English Bible (ed. Pollard) at 2778.

[13] Lloyd E. Berry erroneously claims, 'Coverdale's Bible was the first to introduce chapter summaries'; in "Introduction," The Geneva Bible: A Facsimile of the 1560 Edition (Peabody, Massachusetts: Hendrickson Publishers, 2007) at 3.

$[14]$ David Daniell, The Bible in English (London: Yale University Press, 2003) at 219.

$[15]$ Cleland Boyd McAfee, The Greatest English Classic (New York: Harper and Brothers, 1912; repr., New York: Cosmo Classics, 2005) at 37.

$116]$ Molekamp, "Genevan legacies," at 48;

171 "Parker's note as to the translators," Records of the English Bible (ed. Pollard) at 295-8.

[18] Joseph Lemuel Chester, John Rogers: The Compiler of the First Authorised English

Bible; The Pioneer of the English Reformation; and Its First Martyr (London: Longman,

Green: 1861). 
Claims that present the Matthew summaries as translated directly from the French are found in Molekamp, "Genevan Legacies," at 42; Westbrook, at 41; Frederick Fyvie Bruce, History of the Bible in English, 3rd ed. (Guildford: Lutterworth Press, 1979) at 66; Ariel Hessayon, "The Apocrypha in Early Modern England," The Oxford Handbook of the Bible in Early Modern England, c. 1530 - 1700 (ed. Kevin Killeen, Helen Smith, and Rachel Judith Willie; Oxford: Oxford University Press, 2015) at 136-7; David Daniell, "Rogers, John (c. 1500-1555), Biblical Editor and Martyr," Oxford Dictionary of National Biography. Oxford DNB Online. Mozley and Greenslade admit a degree of originality to Rogers' input, but do not address it, at Mozley, 145 and Greenslade, 151.

Molekamp, "Genevan Legacies," at 42.

Westcott, at 71 .

$[24]$ Mozley notes that the Rogers' summaries for Revelations derive from Coverdale, though does not find them elsewhere; in Mozley, at 145-6.

[25] Mozley, at 157.

[26] Rogers maintains the same spelling of idolatry, 'idolatrye', for all instances aside from its use in the Exod 34 summary. Here, uses the alternate spelling 'ydolatrie', beginning with the ' $y$ ' as the term does in French.

[27] Eve is named five times in the Bible: thrice in the OT (Gen 2.4, 3.20, 4:1) and twice in the NT (2 Cor 11:3, 1 Tim 2:13).

[28] The Lefèvre summaries call her 'Eva' and 'Eve' in the scripture.

[29] The Bible and Holy Scriptures (1560) at HHh3r.

[30] "The Rules to be observed in the Translation of the Bible," Records of the English Bible (ed. Pollard) at 53.

[31] Jeffrey S. Shoulson, Fictions of Conversion: Jews, Christians, and Cultures of Change in Early Modern England (Pennsylvania: University of Pennsylvania Press, 2013) at 110.

[32] David Crystal's Begat: The King James Bible and the English Language (Oxford: Oxford University Press, 2011) at 263.

[33] Ezra Horbury, “Aristotelian ethics and Luke 15.11-32 in early modern England," Journal of Religious History, 41.2 (2017) at 181-96.

[34] “mess, n.1,” OED Online. October 2017. Oxford University Press.

[35] John Wycliffe's Bible translates the term as 'hill'.

[36] Harvey K. McArthur, Understanding the Sermon on the Mount (London: Epworth Press, 1961) at 11; Henry Edwin Savage, The Gospel of the Kingdom: Or, The Sermon on the Mount, Considered in the Light of Contemporary Thought and Ideals(London: Longmans, Green: 1910) at 28. 
J. F. Bethune-Baker, "The Sermon on the Mount," The Rise of the Christian Church (ed. J. F. Bethune-Baker; Cambridge: Cambridge University Press, 1929) at 319; "sermon, n, 2e", OED Online. June 2017. Oxford University Press.

[38] McArthur, at 161 n. 1.

[39] John Florio, A World of Words (London: 1598) at 451.

[40] “seduce v.", OED Online. October 2017. Oxford University Press.

[41] Thomas Cranmer, Certayne sermons, or homelies (London: 1547) at H4r.

${ }^{[42]}$ George Gifford, A catechisme conteining the summe of Christian religion (London: 1583) at $\mathrm{A} 4 \mathrm{v}$.

[43] Entice is defined as 'to allure' in John Baret, An Alveary or Triple Dictionary, in

English, Latin, and French (London: 1574) at Y6r; it is listed as synonymous with to

'sweetely to draw towardes' in William Thomas' Principal Rules of the Italian Grammar (London: 1550) at B1v.

[44] Nicholas Gibbons, Questions and disputations concerning the Holy Scripture (London: 1601) at 104; Richard Stock, The doctrine and vse of repentance (London: 1610) at 287.

[45] Edward Philips, Certain godly and learned sermons (London: 1607) at 69.

[46] Joseph Hall, Contemplations vpon the principall passages of the holy storie (London: 1612) at 70.

[47] Thomas Bentley, The sixt lampe of virginitie (London: 1582) at 103.

[48] Francis Rollenson, Twelue prophetical legacies (London: 1612) at 267-8.

[49] Francesco Petrarca, “Adamo," Prose (ed. Guido Martellotti; Milan: Riccardo Ricciardi, $1955)$ at 229.

[50] Robert Wolcomb, A glasse for the godly (London: 1612) at 156.

$551]$ William Perkins, A Golden Chaine (London 1591) at L5v-L6r.

[52] Andrew Chertsey, Ihesu: The floure of the commaundementes of god (London: 1510) at P5v.

[53] Thomas Blount, Glossographia or a Dictionary (London: 1656) at N8r.

$54]$ Henry Ainsworth, Annotations upon the five bookes of Moses (London: 1627) at 75.

[55] John Trapp, A clavis to the Bible (London: 1649) at 149; The counter buffe or, Certaine observations upon Mr. Edwards (London: 1647) at 8-9.

[56] Andrewes was previously thought to only use the Geneva, but it has been demonstrated he made use of multiple editions including the KJV; see Peter McCullough and Valentine Cunningham, "Afterlives of the King James Bible," Manifold Greatness: The Making of the King James Bible (ed. Helen Moore and Julian Reid; Oxford: Bodleian Library, 2011) at 141. [57] Lancelot Andrewes, The pattern of catechistical doctrine at large (London: 1650) at 448. 
George Mackenzie, The laws and customes of Scotland (London: 1678) at 161-2. [59]

Samuel Cradock, The history of the Old Testament (London: 1683) at 161.

[60] John Webster, The displaying of supposed witchcraft (London: 1677) at 50.

[61]

John Cotton, An abstract of laws and government (London: 1655) at 25; New-Haven's settling in New-England and some lawes for government (London: 1656) at 23-4;

Massachusetts General Court, Acts and laws passed by the great and general court or assembly of Their Majesties province of the Massachussets-bay (Boston: 1692) at 23.

${ }^{[62]}$ David Norton, The King James Bible: A Short History from Tyndale to Today (Cambridge: Cambridge University Press, 2011) at 1; Gordon Campbell, Bible: The Story of the King James Version 1611-2011 (Oxford: Oxford University Press, 2010) at 1. 